\title{
Corona Virus: A Pandemic Going Viral
}

\author{
Sarah Farhat ${ }^{1 *}$, Sabah Ansar ${ }^{2}$ \\ ${ }^{1}$ Lawrence High, Lawrence, Kansas, USA \\ ${ }^{2}$ Clinical Laboratory Sciences, Applied Medical Sciences, King Saud University, USA
}

\begin{abstract}
DOI: $\underline{10.36348 / \mathrm{sijb} .2020 . \mathrm{v} 03 \mathrm{i} 04.003}$
| Received: 01.04.2020 | Accepted: 09.04.2020 | Published: 29.04.2020
\end{abstract}

*Corresponding author: Sarah Farhat

\section{Abstract}

In 2020, the worldwide corona virus outbreak has officially been declared a pandemic by the World Health Organization (WHO). According to the WHO, a pandemic is the worldwide spread of a new disease. A pandemic is when an epidemic spreads between countries. Numerous viral infections have arisen and affected global healthcare facilities. HIV/AIDS, bubonic plague, smallpox, cholera, flu and influenza caused by virus are some of the most brutal killers in human history. Corona viruses cause common cold and infections which are generally self-resolving. Any outbreaks of these diseases across international borders are properly defined as pandemic, especially smallpox which throughout history has killed between 300-500 million people in its 12,000 year existence. Millions of individuals are at serious chance of obtaining a few advancing viral contaminations.

Keywords: Corona virus, infection, SARS, MERS, pandemic

Copyright @ 2020: This is an open-access article distributed under the terms of the Creative Commons Attribution license which permits unrestricted use, distribution, and reproduction in any medium for non-commercial use (NonCommercial, or CC-BY-NC) provided the original author and source are credited.

\section{INTRODUCTION}

It is intriguing to think that a small string of RNA can bring the world to its knees in 2020! During the last few years, corona viruses have become the most important worldwide because of the incidence of several deaths caused by them [1,2]. The 2019 novel corona virus is one of seven members of this family known to infect humans and the third in the past three decades to jump from animals to humans. First emerging in China in December, this new corona virus has caused a global health emergency [3-5]. Since 2003 , corona virus has caused multiple major public health events that resulted in global epidemics such as, severe acute respiratory syndrome - Severe Acute Respiratory Syndrome (SARS), Middle East respiratory syndrome (MERS ) and corona virus disease 2019 COVID-19. Severe acute respiratory syndrome (SARS) was considered among newly emerged infectious diseases with a major morbidity and mortality, when it was first identified in 2002 in China. Due to a high case fatality rate, accurate knowledge of the SARS-CoV remains a priority. Especially since COVID-19 has out broken in Wuhan, Hubei, in December 2019, corona virus has had a significant impact on people's health and lives. But so far, the pathological diagnosis of COVID-19 has been relatively deficient [6-8].
Common indications of the Crown infection incorporate a fever, flu-like side effects such as hacking, sore throat and weakness, and shortness of breath. Past considers had detailed relationship between counter acting agent status to bovine crown infection and lower respiratory tract illness [9-12]. The Middle East respiratory syndrome corona virus (MERS-CoV) is a novel positive sense single stranded ribonucleic acid virus of the genus Beta corona virus [13]. The 2015 epidemic of Middle East respiratory syndrome (MERS) in the Republic of Korea has been the largest outbreak outside Middle East. This epidemic caused 185 laboratory-confirmed cases and 36 deaths in the Republic of Korea until September 2, 2015 [14, 15].

In humans, corona viruses cause respiratory tract infections that can be mild such as some cases of the common cold and others that can be lethal, such as SARS, MERS, and COVID-19 [6]. Symptoms in other species vary: in chickens, they cause an upper respiratory tract disease, while in cows and pigs they cause diarrhea. There are yet to be vaccines or antiviral drugs to prevent or treat human corona virus infections. They are enveloped viruses with a positive-sense single-stranded RNA genome and a nucleocapsid of helical symmetry. The genome size of corona viruses ranges from approximately 27 to 34 kilobases, the largest among known RNA viruses [4, 16, 17]. 
The name corona virus is derived from the Latin corona, meaning "crown" or "halo", which alludes to the characteristic appearance reminiscent of a crown or a solar corona around the virions (virus particles) when viewed under two-dimensional transmission electron microscopy, due to the surface being covered in club-shaped protein spikes. The hemagglutininesterases (HEs) are a family of viral envelope glycoprotein that mediates reversible attachment to $\mathrm{O}$ acetylated sialic acids by acting both as lectins and as receptor-destroying enzymes (RDEs). Related HEs occur in influenza $\mathrm{C}$, and corona viruses apparently as a result of relatively recent lateral gene transfer events [18].

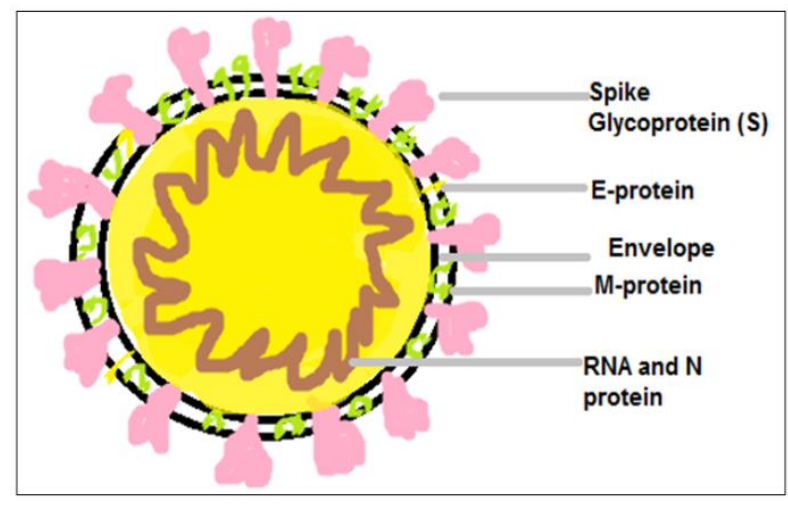

Cross-sectional model of a Corona virus

The coronavirus spike protein is a multifunctional molecular machine that mediates coronavirus entry into host cells. It first binds to a receptor on the host cell surface through its S1 subunit and then fuses viral and host membranes through its S2 subunit. Two domains in S1 from different coronaviruses recognize a variety of host receptors leading to viral attachment. The most important structural proteins of $\mathrm{CoV}$ are spike (S) protein (trimeric), membrane (M) protein, envelop (E) protein, and the nucleocapsid $(\mathrm{N})$ protein. Some of the viruses such as beta-CoVs also have hemagglutinin esterase (HE) glycoprotein [19] The RNA genome of CoV has seven genes that are conserved in the order: ORF1a, ORF1b, S, OEF3, E, M, N in 5' to 3' direction. The twothird part of the RNA genome is covered by the ORF1a/b, which produces the two viral replicase proteins that are polyproteins (PP1a and PP1ab)[20].

Sixteen mature nonstructural proteins (NSPs) emerge from further processing of these two PPs. These NSPs take part in different viral functions including the formation of the replicase transcriptase complex. The remaining genome part of the virus encodes the mRNA which produces the structural proteins, i.e., spike, envelope, membrane, and nucleocapsid, and other accessory proteins [20] Another important envelopassociated protein which is expressed by only some strains of $\mathrm{CoV}$ is the $\mathrm{HE}$ protein [21]. The RNA genome of $\mathrm{CoV}$ is packed in the nucleocapsid protein and further covered with envelope [22].
Sanitization or hand washing with cleanser is one of the essential means to prevent the spread of infections and hand hygiene in primary care settings [23]. Older people are at higher risk for severe illness from COVID-19 may result in increased stress during a crisis [8, 24]. Hearing about the pandemic repeatedly can be upsetting. Taking care of your body is recommended to take deep breaths, stretch, or meditate along with eating healthy, well-balanced meals, exercise regularly, get plenty of sleep, and avoiding alcohol and drugs. Also, strong health care system is needed for global corona pandemic [25].

However, there are seven major targets (spike protein, envelop protein, membrane protein, protease, nucleocapsid protein, hemagglutinin esterase, and helicase) for which drug design can be considered [26]. There are other 16 nonstructural proteins (NSPs), which can also be regarded from the drug design perspective. The major structural proteins and NSPs may serve an important role from drug design perspectives.

\section{CONCLUSION}

The 2019-novel coronavirus (nCoV) is a major source of catastrophe in the 21th century. Viruses do not comply with laws, and do not always behave predictably. They have one primary purpose: to build and pass on copies of themselves. They do not have any inherent malevolence, but simply the imperative to find a new hos $t$ to live in, as they will perish without such defense. The event of frequent occurrence is a major deterrent factor toward the development of $\mathrm{CoV}$-specific vaccines/drugs. Nevertheless, at this point in time, the absence of effectiv e Medication/s to prevent or treat an assault is a significa nt concern.

\section{REFERENCES}

1. Al-Osail, A. M., \& Al-Wazzah, M. J. (2017). The history and epidemiology of Middle East respiratory syndrome corona virus. Multidisciplinary respiratory medicine, 12(1), 20.

2. Al-Hazmi, A. (2016). Challenges presented by MERS corona virus, and SARS corona virus to global health. Saudi journal of biological sciences, 23(4), 507-511.

3. Yang, P., Liu, P., Li, D., \& Zhao, D. (2020). Corona Virus Disease 2019, a growing threat to children?. Journal of Infection.

4. Zhang, H. W., Yu, J., Xu, H. J., Lei, Y., Pu, Z. H., Dai, W. C., ... \& Li, M. (2020). Corona virus international public health emergencies: implications for radiology management. Academic Radiology, 27(4):463-467.

5. Zhu, Z. B., Zhong, C. K., Zhang, K. X., Dong, C., Peng, H., Xu, T., ... \& Zhang, Y. H. (2020). Epidemic trend of corona virus disease 2019 (COVID-19) in mainland China. Zhonghua yu fang yi xue za zhi [Chinese journal of preventive medicine], 54, E022-E022. 
6. Wang, H. J., Du, S. H., Yue, X., \& Chen, C. X. (2020). Review and Prospect of Pathological Features of Corona Virus Disease. Fa yi xue za zhi, 36(1), 16-20.

7. Xu, K., Cai, H., Shen, Y., Ni, Q., Chen, Y., Hu, S., ... \& Qiu, Y. (2020). Management of corona virus disease-19 (COVID-19): the Zhejiang experience. Zhejiang da xue xue bao. Yi xue ban= Journal of Zhejiang University. Medical sciences, 49(1), 1-10.

8. Yang, H. Y., \& Duan, G. C. (2020). Analysis on the epidemic factors for the Corona Virus Disease. Zhonghua yu fang yi xue za zhi [Chinese journal of preventive medicine], 54, E021.

9. Ieki, R. (2010). Corona virus, Nihon Rinsho, 68 Suppl 6, 367-71.

10. Ohlson, A., Emanuelson, U., Tråvén, M., \& Alenius, S. (2010). The relationship between antibody status to bovine corona virus and bovine respiratory syncytial virus and disease incidence, reproduction and herd characteristics in dairy herds. Acta Veterinaria Scandinavica, 52(1), 37.

11. Beaudeau, F., Björkman, C., Alenius, S., \& Frössling, J. (2010). Spatial patterns of bovine corona virus and bovine respiratory syncytial virus in the Swedish beef cattle population. Acta Veterinaria Scandinavica, 52(1), 33.

12. Oosterhof, L., Christensen, C. B., \& Sengeløv, H. (2010). Fatal lower respiratory tract disease with human corona virus NL63 in an adult haematopoietic cell transplant recipient. Bone marrow transplantation, 45(6), 1115-1116.

13. Al-Hameed, F. M. (2017). Spontaneous intracranial hemorrhage in a patient with Middle East respiratory syndrome corona virus. Saudi medical journal, 38(2), 196-200.

14. Xia, Z. Q., Zhang, J., Xue, Y. K., Sun, G. Q., \& Jin, Z. (2015). Modeling the transmission of Middle East respirator syndrome corona virus in the Republic of Korea. PloS one, 10(12):e0144778.

15. Struck, A. W., Axmann, M., Pfefferle, S., Drosten, C., \& Meyer, B. (2012). A hexapeptide of the receptor-binding domain of SARS corona virus spike protein blocks viral entry into host cells via the human receptor ACE2. Antiviral research, 94(3), 288-296.

16. Wang, J., Liu, J., Wang, Y., Liu, W., Chen, X., Sun, C., ... \& Ruan, L. (2020). Dynamic changes of chest $\mathrm{CT}$ imaging in patients with corona virus disease-19 (COVID-19). Zhejiang da хие хие bao. $Y i$ xue ban= Journal of Zhejiang University. Medical sciences, 49(1), 0.
17. Wang, J., Wang, B. J., Yang, J. C., Wang, M. Y., Chen, C., Luo, G. X., \& He, W. F. (2020). Advances in the research of mechanism of pulmonary fibrosis induced by Corona Virus Disease 2019 and the corresponding therapeutic measures. Zhonghua shao shang za zhi= Zhonghua shaoshang zazhi= Chinese journal of burns, 36, E006.

18. Zeng, Q., Langereis, M. A., van Vliet, A. L., Huizinga, E. G., \& de Groot, R. J. (2008). Structure of coronavirus hemagglutinin-esterase offers insight into corona and influenza virus evolution. Proceedings of the National Academy of Sciences, 105(26), 9065-9069.

19. Hilgenfeld, R. (2014). From SARS to MERS: crystallographic studies on coronaviral proteases enable antiviral drug design. The FEBS journal, 281(18), 4085-4096.

20. McBride, R., Van Zyl, M., \& Fielding, B. C. (2014). The coronavirus nucleocapsid is a multifunctional protein. Viruses, 6(8), 2991-3018.

21. Li, F. (2016). Structure, function, and evolution of coronavirus spike proteins. Annual review of virology, 3, 237-261.

22. Guo, Y., Korteweg, C., McNutt, M. A., \& Gu, J. (2008). Pathogenetic mechanisms of severe acute respiratory syndrome. Virus research, 133(1), 4 12.

23. Alfahan, A., Alhabib, S., Abdulmajeed, I., Rahman, S., \& Bamuhair, S. (2016). In the era of corona virus: health care professionals' knowledge, attitudes, and practice of hand hygiene in Saudi primary care centers: a cross-sectional study. Journal of community hospital internal medicine perspectives, 6(4), 32151.

24. Yang, H. Y., Xu, J., Li, Y., Liang, X., Jin, Y. F., Chen, S. Y., ... \& Duan, G. C. (2020). The preliminary analysis on the characteristics of the cluster for the Corona Virus Disease. Zhonghua liu xing bing xие za zhi= Zhonghua liuxingbingxue zazhi, 41, 623-628.

25. De Ceukelaire, W., \& Bodini, C. (2020). We Need Strong Public Health Care to Contain the Global Corona Pandemic. International Journal of Health Services, 0020731420916725.

26. Prajapat, M., Sarma, P., Shekhar, N., Avti, P., Sinha, S., Kaur, H., ... \& Medhi, B. (2020). Drug targets for corona virus: A systematic review. Indian Journal of Pharmacology, 52(1), $56-65$. 